\title{
GOPC/ROS1 Fusion Gene
}

National Cancer Institute

\section{Source}

National Cancer Institute. GOPC/ROS1 Fusion Gene. NCI Thesaurus. Code C99719.

A fusion gene $(\sim 4.1 \mathrm{~kb})$ that results from an interstitial deletion of $240 \mathrm{~kb}$ on $6 \mathrm{q} 21$ which fuses the first 7 exons of the GOPC gene to the last 9 exons of the ROS1 gene. This fusion is associated with g lioblastoma multiforme. 